\title{
Fordi det virker! - Hvordan ideen om evidensbaseret praksis er drivkraft for forandring af lærerprofessionen i folkeskolen
}

Niels Borch Rasmussen, ph.d.-stipendiat, Institut for Statskundskab, Københavns Universitet

Ideen om evidensbaseret praksis undersøges som styringspraksis i en kommunal skoleforvaltning efter folkeskolereformen 2014. I arbejdet med at indføre læringsmålstyret undervisning som didaktisk metode for kommunens lærere, organiseres lærere i forpligtende teamsamarbejder om fælles forberedelse, og vejledes af lærerkolleger på baggrund af observation af undervisningen. Skoleforvaltningens intentioner med at forandre læreres arbejdsform legitimeres med argumentet om, at evidensbaseret viden om elevers læring skal være grundlag for læreres praksis.

Indledning

Evidensbaseret praksis bygger på den grundlæggende tanke, at viden om det, der virker, skal være grundlaget for offentlige velfærdsydelser. Det centrale i evidensbaseret praksis er, at den viden, som skal informere praksis, er sikker viden. Evidensbaseret viden skal derfor komme fra forskningen og handle om det, der har den største effekt i forhold til indsatsens målgruppe. Den forskning, som ligger til grund for evidensbaseret praksis, er forankret i effektstudier, hvor randomiserede, kontrollerede forsøg betragtes som den metode, der skaber den mest sikre viden (Rieper \& Hansen 2009).

Denne artikel handler om, hvordan ideen om evidensbaseret praksis anvendes $i$ styringen (Hansen 2016) af folkeskolen med henblik på at forandre læreres praksis. Evidensbaseret praksis satte for alvor præg på styringen af danske skoler i folkeskolere- 
formen 2014. Allerede i aftaleteksten til reformen fra 2013 mellem den daværende regering (S, SF, R), Venstre og Dansk Folkeparti var ambitionen, at "den nyeste evidensbaserede viden i langt højere grad kommer i spil i den daglige undervisning og det daglige samvær med børnene" (Regeringen 2013, 20). I tråd med denne ambition er reformen 2014 blevet kaldt en læringsreform (Rasmussen 2015), som har fokus på effekt i forhold til elevers læring. Med dette fokus på læringseffekt undergik folkeskolens læringsmål en omfattende revidering. Hvor tidligere læringsmål udtrykte, hvad eleverne indholdsmæssigt skulle lære, er reformens læringsmål nu opbygget omkring, hvad eleverne skal kunne med udgangspunkt i overordnede kompetencemål (Rasmussen \& RashChristensen 2015).

Et åbenlyst eksempel på evidensbaseret praksis er læringsmålstyret undervisning (LSU), som er udviklet til lærernes arbejde med reformens læringsmål. I sommeren 2014 udgav Undervisningsministeriet en vejledning i Læringsmålstyret undervisning til at omsætte reformens læringsmål i undervisningen. LSU er en didaktisk metode, som omfatter planlægning, gennemførelse og evaluering af undervisningsløb og er $\mathrm{i}$ grundtræk baseret på skoleforskeren John Hatties evidensbaserede forskning (Hattie 2009). I et omfattende statistisk meta-review har Hattie identificeret de faktorer, der har størst effekt $\mathrm{i}$ forhold til elevers læring, og har på baggrund af disse udviklet den didaktiske metode, Visible Learning. De to faktorer, som Visible Learning bygger på, er at tydeliggøre for eleverne, hvad de skal lære, og at give eleverne feedback på, om de har nået læringsmålene.

Fra et styringsperspektiv betyder evidensbaseret praksis, at viden om det, der virker, fremføres som et selvstændigt argument for centrale elementer af reformen 2014. En kontorchef fra Undervisningsministeriet begrunder vejledningen i LSU med henvisning til John Hatties evidensbaseret forskning: "Vejledningen har baggrund i forskningsresultater, der viser, at tydelige mål, feedback og evaluering har positiv betydning for elevernes læring" (Olsen 2016). Også i selve vejledningen er det tydeligt, at grundtanken i evidensbaseret praksis er hovedargumentet for, at lærere skal arbejde med LSU: "Og hvorfor loeringsmålstyret undervisning? Fordi det virker" (UVM 2014a, 3). Evidensbaseret praksis kan således betragtes som en egentlig styringslogik (Hansen 2013), der har sin autoritetsbase i evidensbaseret forskning og bærer på et overordnet narrativ om, at professionel praksis skal være funderet i viden om det, der virker. Foruden John Hatties visible learning er en række koncepter og metoder blevet fremhævet som evidensbaseret viden og har vundet stor udbredelse i den danske folkeskole efter reformen 2014. Koncepter som professionelle læringsfællesskaber (Albrechtsen 2013) og elevcentreret læringsledelse (Robinson 2011) er alle baseret på effektstudier og knytter an til narrativet om, at viden om det, der virker, skal informere praksis.

Spredningen af evidensbaseret viden har samtidig skabt en spænding i forhold til den grad af autonomi, som traditionelt har karakteriseret lærerprofessionen. Denne spænding gør sig især gældende i debatten om LSU, der specifikt omhandler læreres tradition for metodefrihed. Den akademiske litteratur har hovedsageligt handlet om det konceptuelle grundlag for LSU, og i hvilken grad LSU kan siges at været funderet i evi- 
densbaseret viden (Laursen 2015; Rømer 2016; Skovmand 2016; Qvortrup 2015; Tanggaard et al. 2014). Den eksisterende pædagogiske litteratur om evidens og LSU har et snævert fokus på LSU som didaktisk metode. Dermed overser litteraturen det bredere spørgsmål om, hvordan LSU forandrer lærerprofessionen efter reformen. I et større perspektiv er dette spørgsmål vigtigt $\mathrm{i}$ forhold til at forstå, hvordan et stigende fokus på evidens forandrer professioner på tværs af velfærdsområder. Forskningen er generelt optaget af at undersøge, hvad evidensbaseret viden er, og hvordan den overføres til praksis, men mangler et blik for, hvad implementering af evidensbaseret viden betyder for, hvad en professionel i velfærdsstaten er og gør. Til at undersøge forandringer i lærerprofessionen er artiklen forankret $\mathrm{i}$ et praksisperspektiv ud fra den tilgang, at professioner er, hvad professioner gør. I dette perspektiv er professioner forstået med udgangspunkt i organisatorisk praksis, og i forlængelse heraf sker professionel forandring i takt med ændringer i organisatorisk praksis (Noordegrad 2011).

Et centralt spørgsmål i artiklen er, hvad det er for en forandring af lærerprofessionen, som implementering af LSU indebærer. Med udgangspunkt $\mathrm{i}$ et organisatorisk praksisperspektiv er fokus dels på, hvordan lærere er organiseret om arbejdet med LSU, og dels hvordan en ny organisering af lærere bliver udviklet. Det er kommunale skoleforvaltninger og skolelederes opgave at implementere reformens læringsmål i undervisningen i folkeskolen. Det interessante er, at reformen 2014 ikke giver specifikke anvisninger på, hvordan den enkelte folkeskole skal organisere læreres arbejde med LSU. Der er således et åbent spillerum for at udvikle nye organiseringsformer til at understøtte læreres arbejde med reformens læringsmål. I artiklen undersøger jeg, hvordan narrativet om evidensbaseret praksis er drivkraft for den måde, en skoleforvaltning udvikler en ny organisering af lærere. Endelig undersøger jeg, hvordan skoleforvaltningen anvender narrativet om evidensbaseret praksis til at retfærdiggøre forandring over for skolens lærere. Begrebet legitimitet anvendes til at undersøge skoleforvaltningens retfærdiggørelse og vil blive behandlet $\mathrm{i}$ artiklens teoriafsnit.

Analysen er baseret på et casestudie af skoleforvaltningen i Glostrup Kommune, for at nå en dyb forståelse af forbindelsen mellem evidensbaseret praksis og forandring af lærerprofessionen, som er en generel problemstilling i folkeskolen (Flyvbjerg 2006). Glostrup Kommune søgte i efteråret 2014 midler i AP-Møllerfonden til udviklingsprojektet, "Tæt på Læringseffekten” (TLP). TPL består af en ny organisering af lærere med det formål at understøtte lærernes arbejde med LSU. Denne nye organisering er en radikal omformning af den måde, lærerne hidtil har været organiseret, og indebærer en redefinering af lærernes professionelle praksis i kommunens folkeskoler.

Som det ofte er tilfældet har en case både specifikke og generelle træk. Jeg har valgt skolesystemet i Glostrup Kommune som case, fordi kommunen har prioriteret at indføre LSU som metode for lærere særlig højt. Dette betyder, at lærere i den typiske danske folkeskole ikke nødvendigvis er organiseret omkring brugen af LSU, som tilfældet er i Glostrup Kommune. Casen er dermed valgt ud fra, at den indeholder informationer om, hvordan indførelse af LSU forandrer læreres professionelle praksis (Flyvbjerg 2006). Selvom casen ikke nødvendigvis er typisk for landets folkeskoler, har casen alli- 
gevel relevans for den generelle forskning i den danske folkeskole efter reformen 2014. Den dybdegående undersøgelse af, hvordan indførelse af LSU forandrer læreres professionelle praksis i Glostrup, bidrager empirisk til en generel diskussion om forholdet mellem evidensbaseret praksis som styringslogik og forandringer af lærerprofessionen.

Artiklens to undersøgelsesspørgsmål er: Hvilken betydning har ideen evidensbaseret praksis for den måde forvaltningen i Glostrup Kommune 1) redefinerer loereres professionelle praksis og 2) legitimerer denne nye praksis over for kommunens loerere?

Legitimitet, ideer og oversættelser

Meyer og Rowan argumenterede i en klassisk artikel fra 1977 for, at samfundet er domineret af institutionaliserede rationaliserede normer. Disse såkaldte rationelle myter spredes i samfundet, ikke nødvendigvis fordi de bidrager til at gøre organisationer mere effektive, men fordi organisationer er nødsaget til at indoptage institutionaliserede normer for at blive opfattet som legitime.

Legitimitet er forblevet et centralt begreb i udviklingen af sociologisk institutionel teori. En bredt anerkendt forståelse af begrebet er, at der inden for et socialt system af normer, værdier og meninger eksisterer en generel opfattelse af, at bestemte handlinger er ønskede, korrekte og passende (Suchman 1995, 574). Én form for legitimitet er kognitiv legitimitet, som er udtryk for bestemt viden, der har ophøjet status i et socialt system. Legitim viden anvendes til at forme organisationers praksis, mens anden viden udelades. Viden har højest legitimitet, når den internaliseres af aktører og betragtes som taget for givet (Fiol \& Aldrich), rationel og objektiv i det sociale system (Meyer og Rowan 1977). Ruef og Scott (1998) skelner desuden mellem organisationens eksterne og interne legitimitet. Ekstern legitimitet er rettet mod aktører i organisationens omgivelser og søges ifølge Meyer og Rowan for at tiltrække ressourcer til organisationen. I artiklens analyse søger Glostrup Kommune at fremstå legitim over for APMøllerfonden af den simple årsag, at fonden er finansieringskilde til TPL-projektet. Samtidig er intern legitimitet blandt kommunens lærere nødvendig for, at projekt TPL kan lykkes med skabe den ønskede forandring i kommunens skoler.

Et andet centralt anliggende for sociologisk institutionel teori er, hvad denne legitimerede viden består af - eller med andre ord, hvad det er for materiale, der spredes i samfundet. Meyer og Rowan pegede på, at rationaliseret, legitimeret viden hentes ind $\mathrm{i}$ organisationer, hvor den sættes sammen som byggeklodser til at udgøre organisationers formelle strukturer (Meyer og Rowan 1977, 345). Meyer og Rowan præciserer imidlertid hverken, hvad denne legitime viden består af, eller hvordan viden hentes ind og sammensættes i organisationen (Townley 2002). Derimod tilbyder institutionel oversættelsesteori (Røvik 2007), som udspringer af sociologisk institutionel teori, en teoretisering af, hvordan organisationer indoptager legitimeret viden fra organisationens omgivelser. Omdrejningspunktet for institutionel oversættelsesteori er ideer, der bevæger sig 
eller oversættes fra en kontekst til en anden. I artiklen undersøger jeg, hvordan ideer som evidensbaseret praksis og LSU oversættes fra folkeskolesektorens kontekst til organisationens. Det centrale bidrag fra oversættelsesteorien er, at ideer forandrer sig i denne rejse mellem kontekster.

Jeg skelner mellem ideer på to analytiske niveauer. Dels er organisationsideer udtryk for koncepter eller metoder, der indoptages og oversættes til praksis i organisationen. LSU er udtryk for en sådan organisationsidé. Dels er masterideer udtryk for en mere abstrakt idé, der består at et samlende narrativ om organisatorisk forandring. Evidensbaseret praksis konceptualiseres i artiklen som en masteride.

\section{Organisationsideer}

Organisationsideer findes i forskellige former som managementkoncepter, metoder, standarder og organisationsformer. Røvik (2007) kalder oversættelsen af ideer, som hentes ind i organisationen og oversættes til praksis, for en kontekstualisering af ideen. En central pointe i kontekstualisering er, at ideers oversættelse i organisationen følger andre spor, end hvad der kan forklares $i$ en rationel implementeringsmodel (Røvik 2007). Der er empirisk belæg for, at abstrakte organisationsideer, som findes i organisationens institutionelle omgivelser, ikke kopieres én til én, når de implementeres i organisationen, men kræver, at den abstrakte ide bliver oversat til organisationens kontekst (ibid.).

De aktører i organisationen, der skaber denne forbindelse mellem den abstrakte ide og organisationens kontekst, kaldes oversættere. Røviks begreb om oversættereren harmonerer med et dualistisk syn på struktur-agens problematikken, som er fremtrædende i senere sociologisk institutionel teori. Aktørers mening, kompetence og viden er formet i det institutionelle miljø, men aktører navigerer samtidig kreativt og refleksivt i denne institutionelle kontekst (Lawrence \& Suddaby 2006). Organisatorisk forandring foregår som følge af aktørers intenderede handlinger, og det er gennem indsigt i aktørers intentioner, at analysen belyser, hvordan læreres professionelle praksis forandres og legitimeres. I analysen af Glostrup Kommune kræver implementering af LSU, at der skabes en ny organisering af de lokale skolers lærere, hvilket ikke er anvist i reformen 2014. Oversættelsesarbejdet i Glostrup Kommune handler derfor om at skabe en ny organisering af lærere, som skal understøtte arbejdet med LSU.

Oversættelsesregler er Røviks terminologi til at beskrive, hvad der sker med ideen, når den oversættes i organisationen (Røvik 2007). Oversættere former ideen i oversættelsesprocessen, så den passer til organisationens kontekst. Afhængigt af oversætterens tolkning af idé og den organisatoriske kontekst kan komponenter fra ideen blive fratrukket, mens komponenter fra andre ideer kan blive adderet (tilføjet) i oversættelsen. Ideer kan også blive kombineret eller sammensat og dermed danne en ny idé i organisationen (Røvik 2007, 355). I studiet af Glostrup Kommune er addering den centrale over- 
sættelsesregel, da komponenter fra andre organisationsideer bliver sat sammen for at skabe en ny organisering af lærere.

Masterideer

En masteridé (Czarniawska \& Joerges 1996) er udtryk for en mere abstrakt idé, som ligger bag strømmen af succesfulde organisationsideer i samfundet. Røvik og Pettersen definerer en masteridé, som "en idé som en periode har fått særlig stor legitimitet og utbredelse, og som samtidig gir legitimitet og virker utløsende for lokale reformer i organisasjoner på tvers av sektorer og nasjoner" (Røvik \& Pettersen 2014, 54). Man kan forstå en masteride som et legitimerende narrativ (Czarniawska \& Joerges 1996), som ideer i samfundet kan grupperes efter. Det høje abstraktionsniveau betyder samtidig, at masterideer ikke er direkte handlingsanvisende eller indeholder et koncept, som kan oversættes til praksis. Masterideer består snarere af et perspektiv på problemdefinition og løsning og har en "reformudløsende kraft" (Røvik 2014). I stedet udspringer organisationsideer af masterideen og spredes i samfundet, fordi de trækker på masterideens problemdefinition og løsning. Røvik og Pettersen (2014) foreslår fire masterideer, som gør sig gældende i vor tid; Kvalitet, ledelse, accountability og evidensbaseret praksis. Den sidstnævnte undersøges i denne artikel. Det er kendetegnende for masterideer, at de bygger på en universel idé, som kan strækkes til at passe i forskelligartede kontekster og organisationer. Med andre ord gennemgår masterideen også en forandring i oversættelsesprocessen, når den kontekstualiseres i organisationen.

Et typisk træk ved masterideer er, at de er selvbegrundede. Der stilles sjældent spørgsmålstegn ved masterideer, hvilket betyder, at de eksisterer som institutionaliserede og legitimerede normer i samfundet (Meyer og Rowan 1977). Med masterideer tilføjer Røvik og Pettersen dermed et mere abstrakt analytisk niveau til oversættelsesteorien for at kunne beskrive den institutionelle kontekst for ideer på rejse. Masterideer er i første omgang lagt an på at undersøge, hvorfor nogle ideer er succesfulde på makroniveau (Røvik \& Pettersen 2014). Begrebet rummer imidlertid et potentiale til at berige organisationsstudier i forhold til at forstå, hvilke ideer organisationen søger efter, og hvordan ideer, der hentes ind i organisationen, legitimeres. Røvik og Pettersen skriver:

\footnotetext{
"Når moderne organisasjoner eksponeres for masterideer, har ideene ofte en ekstrem problemdefinerende kraft. Mekanismen som fører til at lokale problemdefinisjoner utvikles i møtet med masterideer, er ofte enkel: En masteridé kan betragtes som en ualmindelige sterk lyskaster som i en periode slås på, og som gir en konsentrert og skarp belysning av noen utvalgte områder og aspekter av moderne organisasjoner" (Røvik \& Pettersen 2014, 55).
}

Masterideer påvirker således organisationen ved at definere eller sætte fokus på, hvad der er organisationens udfordringer. Organisationen indleder derefter en søgning efter 
organisationsideer $\mathrm{i}$ form af koncepter eller metoder, der tilbyder handlingsanvisende løsninger på organisationens udfordringer.

Data, metode og analysestrategi

I 2012 blev Glostrups fire folkeskoler lagt sammen til Glostrup Skole under én strategisk skoleledelse. Artiklens datagrundlag er indsamlet og udvalgt på baggrund af et indgående kendskab til Glostrup Kommunes skolesystem. I løbet af to og et halv år har jeg foretaget observationsstudier, indsamlet en omfattende dokumentsamling, gennemført spørgeskemaundersøgelse og foretaget omkring 40 interviews med lærere, lokale skoleledere og medarbejdere i skoleforvaltningen.

Artiklens data består af styringsdokumenter og interview, som er indsamlet på følgende måde: Ud fra en større dokumentsamling fra Glostrup Skole har jeg udvalgt styringsdokumenter, som var relevante for artiklens analyse. Det centrale dokument er projektbeskrivelsen for TPL, men i analysen inkluderes også tilhørende dokumenter og PowerPoint-præsentationer, som forvaltningen har udarbejdet for at formidle projektet til ledere og medarbejdere. På baggrund af min viden om Glostrup Kommunes skolesystem har jeg identificeret og interviewet de to personer fra Center for Dagtilbud og Skole (herefter blot forvaltningen), som har stået bag udviklingen af projekt TPL. Det ene interview er med en skolekonsulent i forvaltningen, der har arbejdet med at udvikle projekt TPL, og det andet interview er med forvaltningens centerleder, der har taget initiativet til TPL. Både skolekonsulenten og centerlederen har desuden formidlet projekt TPL til Glostrup Skoles lærere og ledere. Interviewene havde begge en varighed på lidt over en time, og til interviewet med centerlederen var skolekonsulenten også stede og bidrog i samtalen. Begge interview er gennemført i juni 2016.

Interviewene er gennemført med en semistruktureret interviewguide, som jeg har udarbejdet på baggrund af dokumenter om projekt TPL. I tråd med den aktørforståelse, som er beskrevet i teoriafsnittet, har jeg i interviewene forsøgt at indfange forståelsen af og intentionerne bag den forandring af læreres praksis, som skolelederen og skolekonsulenten ønskede at skabe med projekt TPL på Glostrup Skole. Det er således gennem disse to centrale aktørers intentionelle handlinger, at jeg ønsker at få indsigt i, hvordan projekt TPL er udviklet og legitimeret over for Glostrup Skole lærere.

Artiklens første undersøgelsesspørgsmål er, hvilken betydning evidensbaseret praksis har for den måde, læreres professionelle praksis er redefineret i projekt TPL.

Metoden for denne del af analysen er at sammenligne forandring i forhold til tid og rum (Gerring 2004). Til at undersøge forandring i tid sammenligner jeg læreres professionelle praksis på Glostrup Skole før reformen 2014 med den professionelle praksis, der er defineret i projekt TPL. I interviewene har jeg spurgt ind til læreres organisatoriske praksis på Glostrup Skole før reformen. Det billede, som især centerlederen tegnede 
af læreres praksis på Glostrup Skole før reformen, stemte overens med det billede, jeg har fra interview med lærere og skoleledere.

Til at undersøge forandring i rum undersøger jeg, hvordan ideer i dansk skolesammenhæng er oversat i projekt TPL. Som det fremgår af teoriafsnittet, forandrer ideer sig, når de oversættes til organisationens kontekst. Analysen har dermed fokus på, hvordan ideer hentes ind og oversættes i projekt TPL. Det er således ved at undersøge, hvordan ideer har forandret sig i oversættelsesprocessen, at jeg ønsker at forstå, hvordan projekt TPL er blevet udviklet. Undersøgelsen af ideers forandring foregår på to analytiske niveauer; masterideen om evidensbaseret praksis og organisationsideer, som organiseringen i projekt TPL udgøres af.

Til at undersøge hvordan masterideen om evidensbaseret praksis er oversat, har jeg først identificeret flere forskellige betydninger af ordet evidens i styringsdokumenterne. Derefter har jeg spurgt interviewpersonerne om disse forskellige betydninger. Jeg har efterfølgende sammenlignet betydninger af evidens i projekt TPL med betydningen i forskningssammenhæng, som er beskrevet i artiklens indledning. Oversættelser af masterideen om evidensbaseret praksis anvendes til at vise, hvordan forvaltningen søger at legitimere projekt TPL eksternt.

Det andet niveau handler om at forstå, hvordan de ideer, som organiseringen af projekt TPL består af, har forandret sig i oversættelsesprocessen. I interviewet med skolekonsulenten har jeg spurgt specifikt til, hvad de forskellige komponenter i projekt TPL består af, og hvilke koncepter og metoder, der ligger til grund for arbejdet med projektbeskrivelsen. Jeg har derefter spurgt skolekonsulenten, hvordan disse ideer er repræsenteret i projektbeskrivelsen, og hvilket formål de har i forhold til at understøtte læreres anvendelse af LSU. Jeg anvender terminologien fra Røviks oversættelsesregler til at beskrive, hvordan ideer fra feltet er oversat og sat sammen i projekt TPL. Spørgsmålet om hvordan forvaltningen redefinerer læreres professionelle praksis undersøges således ved at identificere, hvordan organisationsideer er oversat og sammensat i projekt TPL.

Andet undersøgelsesspørgsmål handler om forvaltningens interne legitimering af en ny professionel praksis over for lærere i Glostrup Skole.

Jeg har anvendt temaet om læreres praksis før reformen 2014 som afsæt til at tale med respondenterne om, hvordan lærere skal arbejde på nye måder. Derefter har jeg med henvisning til projektbeskrivelsen bedt respondenterne reflektere over, hvordan masterideen om evidensbaseret praksis relaterer til den måde, lærere skal arbejde i projekt TPL. Endelig har jeg spurgt ind til spændingen mellem LSU og læreres metodefrihed. Med henvisning til tidligere interview med lærere på Glostrup Skole har jeg præsenteret centerlederen for den holdning, at LSU kolliderer med læreres ret til at vælge egne metoder. Dermed har jeg forsøgt at indfange, hvordan centerlederens argumenter for, at lærere skal anvende LSU og indgå i en ny organisering i Glostrup skole. Spørgsmålet om forvaltningens legitimering af projekt TPL adresseres således ved at undersøge centerlederens argumentation for, at lærere skal arbejde på nye måder.

Analysen er hovedsageligt baseret på citatanalyse af centerlederens og skolekonsulenten forståelser og intentioner. De to respondenter er de eneste ansvarlige personer 
for at udvikle projekt TPL i Glostrup Kommune, og deres perspektiv er derfor dækkende for hele skoleforvaltningens forståelse. Jeg bestræber mig på gennemsigtighed i analysen ved så vidt muligt at præsentere citater for læseren og efterfølgende tolke på betydningen af disse. Det skal i denne sammenhæng bemærkes, at artiklens formål er at undersøge forbindelsen mellem evidensbaseret praksis og forandring af lærerprofessionen. Interviewene er kodet efter den betydning, som masterideen om evidensbaseret praksis spiller i udvikling og legitimering af projekt TPL. Analysens fund giver dermed ikke grundlag for at vurdere betydning af evidensbaseret praksis i forhold til andre faktorer eller fænomener, som kunne have betydning for redefinering af lærerprofessionen.

\section{Analyse}

Analysen indledes med en kort beskrivelse af læreres professionelle praksis på Glostrup Skole før reformen 2014. Beskrivelsen tjener som grundlag for at vise, hvordan læreres professionelle praksis blev redefineret i efteråret 2014.

I 2012 blev Glostrups fire folkeskoler lagt sammen til Glostrup Skole under én strategisk skoleledelse (Glostrup 2016). Ved dannelse af Glostrup Skole fandtes ingen formel organisering, som lærerne var forpligtede til at indgå i. Udgangspunktet for de lokale skolers organisering har været, at den enkelte lærer var ansvarlig for egen klasse, faglighed og didaktiske metoder. I interviews med lærere og ledere på tre af Glostrup Skoles fire skoler benyttes betegnelsen 'den privatpraktiserende lærer' hyppigt af respondenterne til at beskrive den organisatoriske praksis i Glostrup Skole for reformen 2014. Betegnelsen udtrykker en organisatorisk praksis, hvor lærere selv havde ansvar for egen undervisning uden påkrævet indblanding fra ledere og kolleger. Denne beskrivelse udelukker ikke, at lærere har haft tætte ad-hoc samarbejder før reformen, men blot at samarbejdet ikke var formaliseret.

Evidens som drivkraft i projekt 'Tæt på læringseffekten' (TPL)

Det var i forbindelse med en projektansøgning til AP-Møllerfonden, at der i efteråret 2014 blev udviklet en ny organisering af lærere på Glostrups lokale skoler. Nogle måneder efter offentliggørelsen af reformens aftaletekst blev AP-Møllerfondens folkeskoledonation oprettet med det formål at forbedre kvaliteten af undervisningen i folkeskolen. I vejledningen til fondsansøgere fremgik det, at Fonden prioriterede større projekter, der gennemførtes på tværs af - og i samarbejde mellem skoler og kommuner (APMøllerfonden 2014). Forvaltningen indledte derfor et samarbejde med Brøndby og Vallensbæk Kommune om at søge AP-møllerfonden til en ansøgningsrunde i november 2014. 
Undervisningsministeriet udgav vejledningen i LSU i sommeren 2014, og over sommeren blev de tre kommuner enige om, at formålet med projektet skulle være at implementere LSU som metode for kommunernes lærere. Der blev nedsat en arbejdsgruppe bestående af en skolekonsulent fra hver af de tre kommuners skoleforvaltning, og fra sommeren 2014 udarbejdede den såkaldte praksisgruppe en projektbeskrivelse, der blev sendt som ansøgning til AP-Møllerfonden i november 2014. Projektet fik navnet 'Tæt på læringseffekten' (TPL), og de tre kommuner fik bevilget 6,15 millioner kroner, som primært er øremærket uddannelse og opkvalificering af lærere og ledere på Professionshøjskolen UCC. Projektets tidsplan løb fra sommer 2015 til slutningen 2016. Projekt TPL indeholder en ny organisering af lærere i den enkelte folkeskoles organisation. Det er praksisgruppens arbejde med at udvikle en ny organisering af lærere, der er fokus i denne artikel, og jeg identificerer skolekonsulenterne i praksisgruppen som oversættere af LSU fra idé til en ny organisering af lærere.

I tråd med reformen 2014 var et af AP-Møllerfondens ansøgningskriterier at projektansøgninger "baserer sig på evidens" (AP Møllerfonden 2014, 2). I projektbeskrivelsen for TPL optræder ordet 'evidens' i alt ni gange, mens ordet ikke er nævnt i tidligere styringsdokumenter i Glostrup Skole siden dannelsen i 2012. Der er således rimeligt at antage, at orienteringen mod evidens i projektbeskrivelsen er resultatet af vægten på masterideen om evidensbaseret praksis i reformen 2014 og AP-Møllerfonden. Projektbeskrivelsen rummer imidlertid flere betydninger af ordet evidens. Foruden betydningen af evidensbaserede metoder, som svarer til forståelsen i forskningssammenhæng, henviser 'evidens' i projektbeskrivelsen også til, at lærere undersøger og evaluerer egen undervisningspraksis i forhold til kvantificeret performancedata fra standardiserede test. Fælles for disse betydninger af evidens er dog, at de alle bygger på tanken om en datadrevet tilgang til at udvikle undervisningens kvalitet, og de er i den forstand relateret til viden om det, der virker. Den flertydige betydning af ordet evidens bekræfter Røvik og Pettersens pointe om, at masterideer er yderst "strekbare" fænomener, der kan tilpasses enhver kontekst, de oversættes til. At masterideen om evidensbaseret praksis er strakt til flere betydninger i projektbeskrivelsen, tolker jeg således, at ansøgningskommunerne bestræbte sig på at fremstå legitime over for AP-Møllerfondens vurderingsudvalg.

Studiet viser, at legitimitet også virker den anden vej - nemlig ved, at masterideen om evidensbaseret praksis blev opfattet som legitim i praksisgruppen. Dette indebærer, at oversætterne i praksisgruppen har internaliseret det legitimerende narrativ i evidensbaseret praksis. Glostrups skolekonsulent fortæller i interviewet om, hvordan arbejdet i praksisgruppen allerede fra sommeren 2014 var optaget af forbindelsen mellem masterideen om evidensbaseret praksis og ideen LSU:

"Vi ved, at vi skal arbejde mere evidensbaseret, for så er der en større chance for, at det batter noget for eleverne - at vi så rent faktisk gør det, fordi vi ved, at det giver mening... Vi gør det også, fordi vi ved, at forskningen siger, at jo mere tydelige læringsmålene for eleverne er, jo større chance er der for, at de rent faktisk kan forholde sig til det og kan lære noget... Hvordan gør man det her fuldstændigt nede på jorden og 
tydeligt for eleverne, hvad det er, de skal? Hvordan kan man arbejde med feedback? Så det er noget med at få nogle af elementerne ind i vores undervisning. Det har været en kæmpe lang proces at få det her op at stå." (Skolekonsulent, Glostrup)

I citatet har skolekonsulenten fokus på, at undervisningen "batter" i forhold til elevernes læring. Skolekonsulentens opmærksomhed er dermed rettet ind på det fokus, som masterideen om evidensbaseret praksis har på læringseffekt i folkeskolereformen 2014. Udgangspunktet for praksisgruppens arbejde har således været, at feedback til elever og tydelige mål fra Hatties forskning, er de faktorer, som har størst effekt i forhold til elevers læring. Røvik og Pettersens (2014) metafor om en lyskaster kan anvendes til at give et billede af, hvordan masterideen om evidensbaseret praksis har sat spot på et problem og skabt et særligt fokus og formål for praksisgruppens arbejde.

AP-Møllerfonden lagde desuden vægt på, at ansøgningsprojekter havde "praksisnærhed med udgangspunkt i skolens virkelighed", og "at teori omsættes til praksis" (AP-Møllerfonden 2014, 2). I ovenstående citat bemærker skolekonsulenten, at det har været en "kæmpe lang proces" at kontekstualisere den evidensbaserede viden i LSU i de tre kommunale skolesystemer. Det store spørgsmål i praksisgruppens oversættelsesarbejde har således været, hvordan en ny organisering kunne understøtte lærernes arbejde med LSU.
"Hvis det her skal batte noget, så skal vi have en struktur, der kan gribe det. Det nytter ikke noget, at vi poster en masse penge i det, så vi har hele tiden sådan tænkt - men hvad så bagefter og hvordan? Hvor skal de der små kurve eller redder være, som kan gribe det her og få det til at vokse? Hvis ikke du har dem, så bliver det bare regnvand, der siver lige ned i grunden, og det kan vi ikke bruge til noget." (Skolekonsulent, Glostrup)

Fra sommeren 2014 har det primære fokus i praksisgruppen været at fastholde læreres arbejde med LSU i de lokale skolers organisation. Projektbeskrivelsen indeholder derimod ikke en eksplicit beskrivelse af, hvordan lærere skal arbejde med LSU. Oversættelsesarbejdet i praksisgruppen har i stedet handlet om at udvikle en ny organisering af lærerne til at understøtte arbejdet med LSU. Med udgangspunkt i oversættelsesteorien udlægger jeg dette arbejde som en proces, hvor andre ideer blev hentet ind i praksisgruppen og sat sammen for at udgøre en ny organisering i kommunernes skoler.

Det interessante ved dette oversættelsesarbejde er, at masterideen om evidensbaseret praksis har været styrende for, hvilke ideer der blev adderet til LSU i projekt TPL. Om arbejdet i praksisgruppen med at skabe en ny organisering, fortæller skolekonsulenten:

"... det er også noget med at tage det bedste fra alle verdener... vi lægger rigtig mange kræfter i det selv, men nu har vi muligheden, så lad os nu kombinere alt det, vi ved, virker. Så vi har også prøvet at arbejde evidensbaseret i vores planlægning." (Skolekonsulent, Glostrup) 
Praksisgruppen har forsøgt at arbejde "evidensbaseret" i oversættelsesprocessen ved at kombinere alt det, de ved, virker. Evidensbaseret praksis som masteride kan i den forstand forstås som et søgekriterium for ideer i samfundet, der kan understøtte lærernes arbejde med LSU. Dette indebærer, at det især var ideer, som signalerede, at de havde en dokumenteret effekt, der blev hentet ind i praksisgruppen. Masterideen om evidensbaseret praksis fungerede derfor som et samlende narrativ, der ikke blot legitimerer LSU, men også organiseringen i TPL. I det følgende vises, hvordan oversættelsesarbejdet er karakteriseret ved, at andre ideer er blevet adderet og sat sammen som byggeklodser for at bruge Meyer og Rowans udtryk (1977), for at skabe en ny organisering for læreres brug af LSU.

\section{Redefinering af læreres professionelle praksis}

De ideer, som er adderet til LSU i projekt TPL, har alle vundet stor udbredelse i folkeskoleskolen og er, med en enkel undtagelse, forbundet med evidensbaseret viden. Projekt TPL består af komponenter fra tre identificerbare ideer: 1. ideen om pædagogisk ledelse (Robinson 2011), der handler om, at skolelederens faglige sparring med lærere har stor betydning for læringseffekten, 2. ideen om læreres teamsamarbejde i professionelle læringsfællesskaber (Albrechtsen 2013) og endelig 3. ideen om aktionslæring (Plauborg \& Bayer 2007), som ikke er direkte knyttet til evidensbaseret viden, men kommer fra pædagogfaget og har spredt sig til lærerprofessionen. På den måde er projekt TPL på den ene side et partikulært produkt af praksisgruppens kontekstualisering af populære ideer i skolesammenhæng, og på den anden side udtryk for en generel udvikling i den danske folkeskole.

Organiseringen af lærere består af to niveauer. På første niveau er lærerne organiseret $\mathrm{i}$ fælles forberedende team (FF-team). FF-team er såkaldte fagfaglige team, der så vidt muligt består af lærere fra samme fag og på samme klassetrin. FF-team er konstrueret ud fra ideen om professionelle læringsfællesskaber, hvor lærere i teamet skal samarbejde om at udvikle fælles undervisningsforløb, som den enkelte lærer efterfølgende skal gennemføre i egen klasse. Det særlige ved konstruktionen af FF-teamet er, at LSU er adderet til ideen om professionelle læringsfællesskaber. De fælles undervisningsforløb skal udvikles inden for rammen af LSU som didaktisk metode, der som nævnt består i at nedbryde reformens fælles mål i læringsmål og opstille et evalueringsdesign for, om eleverne har nået deres mål.

På andet niveau skal en mindre gruppe lærere på skolerne uddannes til en særlig vejlederfunktion i projekt TPL. Vejledernes funktion er at understøtte FF-teamene i arbejdet med LSU. Metoden for denne vejledning kommer fra ideen om aktionslæring. Aktionslæring består $\mathrm{i}$, at lærere observerer hinandens undervisning og giver feedback på baggrund af en problemstilling i undervisningen, som den lærer, der skal observeres, 
selv har valgt. Den komponent i aktionslæring, der handler om at lærere selv skal vælge en problemstilling, er fratrukket i projektbeskrivelsen, mens ideen om LSU er adderet til ideen om aktionslæring. I projekt TPL er det således ikke en problemstilling efter lærerens eget valg, men LSU, som er omdrejningspunktet for aktionslæring. Samtidig er ideen om pædagogisk ledelse adderet til ideen om aktionslæring, ved at vejlederen skal anvende aktionslæring som dialogredskab i vejledningen. Vejlederens opgave er at støtte øvrige lærere $\mathrm{i}$ at formulere tydelige mål, give feedback til elever og evaluere elevers læring. Vejlederen skal "hjælpe ledelsen tættere på praksis" ved at "understøtte og kvalificere faglig pædagogisk ledelse tæt på praksis" (Glostrup 2015). Dermed har vejlederen i projekt TPL en særlig tilknytning til ledelsen på de lokale skoler. Vejlederen får distribueret en pædagogisk ledelsesopgave og bliver en form for bindeled mellem den lokale skoleleder og de øvrige lærere. Ideen om aktionslæring og pædagogisk ledelse kobles sammen, hvilket betyder, at grundtanken i aktionslæring om en ligeværdig dialog mellem lærerkolleger er fratrukket i projektbeskrivelsen. Studiet af praksisgruppens arbejde viser, at det ikke giver mening af følge den enkelte ides oversættelse som en isoleret proces. For at forstå, hvordan komponenter er adderet og fratrukket den enkelte ide, skal ideens oversættelse undersøges som en del af praksisgruppens arbejde med at udvikle en ny organisering af lærere, til at understøtte arbejdet med LSU.

På baggrund af ovenstående består projekt TPL af en ny organisering, der indebærer en redefinering af læreres professionelle praksis i forhold til den "privatpraktiserende lærer", som kendetegnede organiseringen på Glostrup Skole før reformen 2014. Lærernes professionelle praksis redefineres på særligt tre områder: For det første er lærerne forpligtet til at arbejde med LSU som didaktisk metode til at operationalisere de fælles mål i reformen 2014. For det andet skal lærerne tilrettelægge fælles undervisningsforløb, hvilket indebærer et tættere og mere forpligtende samarbejde med lærerkolleger. For det tredje er lærere forpligtede til at åbne undervisningen op for, at vejledere kan observere og forholde sig til lærerens undervisningspraksis. Derudover opstår en ny rolle i organiseringen i form af vejlederen, der fungerer som bindeled mellem ledere og øvrige lærere, som får distribueret et pædagogisk lederskab i forhold til instruere øvrige lærere $\mathrm{i}$ at arbejde med LSU.

Intern legitimering af projekt TPL

Vi har indtil nu set, hvordan masterideen om evidensbaseret praksis har været internaliseret i praksisgruppen og fungeret som ledetråd i udvikling af projekt TPL, der indebærer en redefinering af læreres professionelle praksis. På baggrund af interviewene vil jeg føje endnu en dimension til spørgsmålet om, hvordan masterideen om evidensbaseret praksis er med til at redefinere læreres professionelle praksis. Masterideen om evidensbaseret praksis har ikke blot været styrende for oversættelsesarbejdet i praksisgruppen, men forvaltningens intention er samtidig, at evidensbaseret praksis også skal styre den 
måde, lærere i TPL-projektet tænker om egen praksis. Skolekonsulenten udtrykker forvaltningens ønske om, at det, der virker, skal være det bærende princip for læreres tilgang til eget fag.

"Vi havde nogle helt specifikke ting, som vi gerne ville have, at de [lærere og vejledere] orienterede sig imod. Det var ny viden imod faget, viden om evaluering, viden om noget evidensbaseret, arbejde med evidensbaseret... Og at man så begyndte at forholde sig mere evidensbaseret, og at det man underviser i, og den måde man gør det, det gør man fordi man ved, det virker." (Skolekonsulent, Glostrup)

Som styringsperspektiv handler evidensbaseret praksis således om, at lærere skal være selvstyrende ved selv at hente viden ind i praksis ud fra en vurdering af, om denne viden har effekt i forhold til elevers læring. Lærere skal på den måde have en undersøgende, evaluerende tilgang til egen praksis, som er centreret omkring læringseffekten. Intentionen fra forvaltningen er, at lærere i kommunen internaliserer masterideen om evidensbaseret praksis og vurderer viden i faget ud fra, om denne viden har dokumenteret effekt i forhold til elevers læring.

I interviewet med centerlederen spurgte jeg ind til modsætningen mellem evidensbaseret praksis som styringslogik og læreres metodefrihed.

"Jeg kan stadig høre lærerne sige: 'jamen, vi har jo vores metodefrihed', og så plejer jeg at sige: 'metodefrihed, det ord findes simpelthen ikke $\mathrm{i}$ mit vokabularium. Men du har metodeansvar. Du har ansvar for at vælge den rigtige metode - $\mathrm{i}$ forhold til at eleverne når deres læringsmål, og i forhold til at evaluere på, om eleverne når deres læringsmål.' Så metodeansvar er noget andet end metodefrihed, fordi alle metoder er ikke lige gode." (Centerleder, Glostrup)

For centerlederen er det forkert at opstille en modsætning mellem LSU og læreres metodefrihed. Lærere har som professionelle ansvar for at vælge den rigtige metode. Det er underforstået i citatet, at den rigtige metode, er den metode, som har en dokumenteret effekt i forhold til elevers læring. Det er derfor indlysende, at den ansvarlige lærer arbejder med LSU som didaktisk metode, fordi den har størst effekt i forhold til elevers læring. Lærere, som ønsker at arbejde med metoder, der ikke har dokumenteret effekt, opfattes derimod som uansvarlige fordi de ikke bestræber sig på, at elever "bliver så dygtige, de kan", som det hedder i de nationale mål fra reformen 2014 (Regeringen 2013). Det er derfor meningsløst at tale om læreres metodefrihed, da det er den evidensbaserede forskning, som bedst kan afgøre, hvilken metode der er den rigtige at bruge.

Med centerlederens argumentation kan vi komme tættere på, hvad evidensbaseret praksis indebærer som styringslogik. Den interne legitimering af projekt TPL foregår ved, at centerlederen udfordrer lærere, der er mere optaget af metodefrihed end hvad, der er den "rigtige metode". Underliggende for den interne legitimering af projekt TPL 
er en skarp skelnen mellem legitim og illegitim viden, som findes i masterideen om evidensbaseret praksis. Fra et sociologisk institutionelt perspektiv er selve legitimiteten af evidensbaseret praksis det centrale i spændingen mellem forvaltningen og lærerne på Glostrup Skole. En masteride, som har høj grad af legitimitet, bliver opfattet som objektiv, rationel og taget for givet i organisationen. Hvorvidt projekt TPL opnår intern legitimitet i Glostrup skole afhænger af, om lærerne vil opfatte narrativet om det, der virker, som en rationel selvfølge. Hvordan lærere reagerer på projekt TPL, og hvordan de nye professionelle praksis efterfølgende udfoldes i Glostrups lokale skoler, er spørgsmål for et andet studie.

Konklusion og diskussion

Projekt TPL er udarbejdet i en praksisgruppe bestående af tre skolekonsulenter fra Glostrup Kommune og to nabokommuner, der i efteråret 2014 søgte midler i APMøllerfonden til det projekt, hvis formål var at lærere skulle arbejde med LSU som didaktisk metode i undervisningen. Fra begyndelsen af praksisgruppens arbejde i sommeren 2014 har praksisgruppen arbejdet "evidensbaseret", hvilket betyder, at organiseringen af lærere i projekt TPL er udviklet på baggrund af evidensbaseret viden. Organisering af lærere i TPL indebærer en redefinering af læreres professionelle praksis i forhold til tidligere praksis på Glostrup Skole. Lærere skal være fælles om at udvikle undervisningsforløb på baggrund af LSU som didaktisk metode. Derudover skal vejledere støtte lærere i brugen af LSU ved at observere læreres undervisning og give feedback på brugen af den didaktiske metode.

Intentionen i forvaltningen i Glostrup Skole er endvidere, at evidensbaseret viden skal være et styrende princip for læreres måde at arbejde med deres fag. Lærere skal have fokus på det, der virker i forhold til elevers læring, og indarbejde evidensbaseret viden i egen praksis. Med narrativet om evidensbaseret praksis skelner forvaltningen mellem legitim og illegitim viden. Lærere, som oplever, at evidensbaseret viden kolliderer med lærernes metodefrihed, betragtes som uansvarlige, da LSU opfattes som den "bedste metode", der har en dokumenteret effekt i forhold til elevers læring.

Som vi har set i analysen, er evidensbaseret praksis identificeret som en styringspraksis, der former lærerprofessionen ud fra en skelnen mellem, hvad der er legitim og illegitim viden. Vi har samtidig set, hvordan narrativet om evidensbaseret praksis legitimerer styring af læreres professionelle praksis, som før reformen 2014 har haft en vis autonomi, hvad angår læreres samarbejdsrelationer og metodefrihed. Jeg vil mene, at en sådan styringspraksis hverken er tænkelig eller mulig uden evidensbaseret praksis som det legitimerende narrativ. Det særlige ved evidensbaseret praksis som styringslogik er, at dens legitimitet ikke har base i den parlamentariske styringskæde, men i forskningen. Dette betyder, at evidensbaseret viden kun har legitimitet så længe, denne viden er bredt anerkendt i forskningssammenhæng. Viden, der virker, er hovedargumen- 
tet for, at ledelsen kan beslutte, at lærere skal arbejde med LSU som didaktisk metode. Jeg vil argumentere for, at det, som kan gøre evidensbaseret praksis til en virkningsfuld styringslogik, også er dens svaghed. I det omfang den evidensbaserede viden i reformen 2014 bliver problematiseret, svækkes legitimiteten i styringen tilsvarende.

\section{Litteratur}

Albrechtsen, T. R. S. (2013). Professionelle loeringsfoelleskaber - teamsamarbejde og undervisningsudvikling. Frederikshavn: Dafolo.

AP-Møllerfonden: “Ansøgning”, 2014, www.apmollerfonde.dk/folkeskolen

Czarniawska, B. and Sevón, G. (eds.). (1996). Translating Organizational Change (de Gruyter Studies in Organization 56). Berlin; New York: Walter de Gruyter.

Flyvbjerg, B. (2006). Five Misunderstandings About Case-Study Research. Qualitative Inquiry, vol. 12(2), pp. 219-245.

Gerring, J. (2004). What is a case study and what is it good for?. American Political Science Review, vol. 98(2), pp. 341-335.

Glostrup Kommune. (2016). Evaluering af skole-strukturen. Glostrup, Glostrup Kommune

Glostrup Kommune, Brøndby Kommune og Vallensbæk Kommune. (2014). Tat på laeringseffekten. Ansøgning til AP Møllerfonden

Glostrup Skole. (2015a). Toet på loeringseffekten. Available at: https://prezi.com/mdlgx212pke2/nye-lrere-tt-pa-lringseffekten/

[Accessed 23 May 2017].

Glostrup Skole. (2015b). Q and A forældre. Glostrup Skole.

Hansen, H. F. and Rieper, O. (2009). The Evidence Movement: The Development and Consequences of Methodologies in Review Practices. Evaluation, vol. 15(2), pp. 141-163.

Hansen, H. F. (2013). Systemic Evaluation Governance. New Logics in the Development of Organisational Fields. Scandinavian Journal of Public Administration, vol. 16(3), pp. 47-64.

Hansen, H. F. (2016). Styringsteori. In: A. Berg-Sørensen, C. H. Grøn and H. F. Hansen, ed., Organiseringen af den offentlige sektor, 2. udgave. København: Hans Reitzels Forlag.

Hattie, J. (2008). Visible learning: A synthesis of over 800 meta-analyses relating to achievement. London; New York: Routledge.

Laursen, P. F. (2015). Er Hattie og co. gyldige i Danmark?. Paideia: Tidsskrift for Professionel Pcedagogisk Praksis, pp. 34-41

Lawrence, T. B. and Suddaby, R. (2006). 1.6 institutions and institutional work. The Sage Handbook of Organization Studies. 2. udgave, pp. 215-254, Sage Publications, London 
Meyer, J. W. and Rowan, B. (1977). Institutionalized organizations: Formal structure as myth and ceremony. American Journal of Sociology, vol. 83 (2), pp. 340-363.

Plauborg, H. and Bayer, M. (2007). Aktionslaering: loering i og af praksis. København: Hans Reitzels Forlag.

Qvortrup, L. (2015). Baggrund for og diskussioner af Visible Learning med særligt henblik på lærings-og vidensbegrebet. Paideia: Tidsskrift for Professionel Padagogisk Praksis, pp. 22-33

Rasmussen, J. (2015). Folkeskolereform 2014. Folkeskolen-Efter Reformen. København: Hans Reitzels Forlag.

Rasmussen, J. and Rash-Christensen, A. (2015). Målstyring: Nye Faelles Mål. Folkeskolen-Efter Reformen. København: Hans Reitzels Forlag.

Regeringen. (2013). Et fagligt løft af folkeskolen. Undervisningsministeriet.

Rieper, O., Hansen, H. F. (2007). Metodedebatten om evidens. København: AKF Forlaget.

Robinson, V. (2011). Student-centered leadership. San Fransisco: Jossey-Bass.

Ruef, M. and Scott, W. R. (1998). A Multidimensional Model of Organizational Legitimacy: Hospital Survival in Changing Institutional Environments. Administrative Science Quarterly, vol. 43(4), pp. 877-904.

Røvik, K. A. 2007. Trender og translasjoner: ideer som former det 21. århundrets organisasjon. Oslo: Universitetsforlaget.

Røvik, K. A. and Pettersen, H. M. (2014). Masterideer. In: K. A. Røvik, T. V. Eilertsen and E. M. Furu, ed., Reformideer i norsk skole: spredning, oversettelse og implementering, Oslo: Cappelen Damm Akademisk, pp. 53-79.

Skovmand, K. (2016). Uden mål og med. København: Hans Reitzels Forlag.

Suchman, M. C. (1995). Managing Legitimacy: Strategic and Institutional Approaches. Academy of Management Review, vol. 20(3), pp. 571-610.

Tanggaard, L., Rømer, T. A. and Brinkmann, S. (2014). Uren paedagogik 2, Aarhus: Klim.

UVM. (2014a). Loeringsmålstyret undervisning i folkeskolen - vejledning, København. Undervisningsministeriet. 